\title{
Biochemical, Hematological and Pathological Effects of Bispyribac Sodium in Female Albino Rats
}

\author{
Mahmoud M Elalfy*, Mohamed S Aboumosalam and Fathy R Ali \\ Forensic and Toxicology Department, Faculty of Veterinary Medicine, Mansoura University, Egypt
}

\begin{abstract}
Bispyribac-sodium (nominee (used extensively as a herbicide in rice fields in Egypt. We investigate the cytotoxic effect of bispyribac-sodium in albino rats that intubated orally with $0,16.47,32.94,65.88 \mathrm{mg} / \mathrm{kg}$ of bispyribac-sodium (equivalent to 1/160 1/80 and 1/40 of the LD50 of bispyribac-sodium) for three months twice per week. It was found that bispyribac-herbicide caused non-significant decrease in the body weight gain ratio of albino rats. Moreover, bispyribac-sodium elevated significance levels of ALT, AST, urea, creatinine and LDH. In contrast, bispyribac herbicide decreased significant levels of glucose, cholesterol, total protein and albumin. Bispyribac-sodium showed histopathological changes in liver, lungs, kidney and spleen, but had no significant effect on RBCs count while showing significant increases in leukocyte count. On the conclusions, bispyribac sodium had a toxic effect on liver, lungs and kidney of female albino rats.
\end{abstract}

Keywords: Bispyribac sodium; Liver; Kidney function

\section{Introduction}

Pesticides considered as heterogeneous chemicals used for controlling of plant diseases (pests or weeds) to enhance the productivity of agriculture and yield [1]. As herbicides are some of the most used pesticides worldwide, sub-lethal concentration detection can act as sensitive early alarm tools to indicate their presence and can support for regulatory assessments and monitoring to be not harmed to aquatic life [2].

Herbicides constitute more than $60 \%$ of pesticides that used in agriculture. Most herbicides have low mammalian toxicity due to all herbicides that has hazardous effect on human or animals has been rejected [3]. Bispyribac-sodium (sodium 2, 6-bis [(4, 6-dimethoxy-2pyrimidinyl) oxy] benzoate) belonged to a pyrimidinyl thiobenzoate herbicide [4], is a post emergent herbicide according to Health Canada Pest Management Regulatory Agency (2008) and used mainly to control weeds in rice cultivation (EPA, 2001) $[5,6]$.

The oral LD50\% of bispyribac-sodium in rats was measured to be $4111 \mathrm{mg} / \mathrm{kg}$ body weight in male, while $2635 \mathrm{mg} / \mathrm{kg}$ body weight in female. While its tissue distribution in male larger than female due to superiority in the excretion in female besides repeated administration not affect absorption nor metabolism and excretion [7]. Bispyribac mostly absorbed from gastrointestinal tract completely, had no accumulation effect and excreted mostly as the parent compound and its elimination in male more than female (Australian Pesticides \& Veterinary Medicines Authority 2011) [8].

Technical bispyribac-sodium had low toxicity and increased liver enzyme activity and proliferation of the gall bladder and bile duct where the liver considered the main target organ based on the NOEL in rats (7.2 $\mathrm{mg} / \mathrm{kg}$ bw/day) (Health Canada Pest Management Regulatory Agency, 2008) [5].

Hiroyuki reported that bispyribac-sodium at a dose of 20,000 ppm and/or 50,000 ppm in a four-week study in albino rats, decreased body weight and feed consumption, on necropsy dilatation of the cecum with the proliferation of bile duct and increase in the level of total cholesterol, GPT, GOT, and ALP activities [9]. In a sub-chronic study carried out by the California Environmental Protection Agency, (2001) found that at dose level $1538 \mathrm{mg} / \mathrm{kg} /$ day for 13 weeks on female rats increased relative liver, kidney and spleen weight with microscopic inter and intralobular bile duct proliferation and lymphocytosis in urinary bladder and different body organs [10]. The aim of this study was to evaluate the biochemical parameter changes, histopathological changes and hematological parameters of commercial bispyribac-sodium toxicity in albino rats

\section{Materials and Methods}

\section{Experimental animals and grouping}

Female albino rats obtained from experimental unit, Faculty of pharmacy, Mansoura university; weighted from 95 to $115 \mathrm{GM}$. Animals were apparently healthy and housed in plastic cages contain wood shaving as a bedding material. Animals accommodated for 2 weeks before the experiment and maintained on a balanced ration also feed and water given ad libitium throughout the experiment. Rats divided into four groups each one contains eight rats weighted $115 \pm 5 \mathrm{GM}$; intubated orally with $0,16.47,32.94,65.88 \mathrm{mg} / \mathrm{kg}$ of bispyribac-sodium (equivalent to $1 / 160,1 / 80$ and $1 / 40$ of the LD50 of bispyribac-sodium) for three months twice per week [7]. Animals weighted twice per week before dosing to maintain constant dose throughout the experimental period.

\section{Body weight gain determination}

the body weight was recorded throughout the experiment before each administration; the body weight gain $\%$ calculated according to the following formula [11]:

*Corresponding author: Mahmoud M Elalfy, Forensic and Toxicology Department, Faculty of Veterinary Medicine, Mansoura University, Egypt, Tel: +201007178306 E-mail: mahmoudelalfy@mans.edu.eg

Received August 16, 2017; Accepted August 29, 2017; Published August 30, 2017

Citation: Elalfy MM, Aboumosalam MS, Ali FR (2017) Biochemical, Hematological and Pathological Effects of Bispyribac Sodium in Female Albino Rats. J Vet Sci Technol 8: 467. doi: 10.4172/2157-7579.1000467

Copyright: (๑) 2017 Elalfy MM, et al. This is an open-access article distributed unde the terms of the Creative Commons Attribution License, which permits unrestricted use, distribution, and reproduction in any medium, provided the original author and source are credited. 
Body weight gain $\%=($ Final body weight-Initial body weight $) /$ (Initial body weight $) \times 100$

\section{Biochemical analysis}

Serum of all rats were analyzed for ALT, AST, LDH, total protein, total albumin, serum Glucose, urea according to Burtis at al., serum creatinine and cholesterol levels [12-19].

\section{Hematology}

Blood taken from the apex of the left ventricle of the heart with a syringe, then collected in gel tubes contain EDTA as an anticoagulant and the blood sample analysis was carried out by hematological analyzing. Where hemoglobin (HGB), red blood cell count (RBC), mean corpuscular volume (MCV), hematocrit (HCT), mean corpuscular hemoglobin $(\mathrm{MCH})$ and mean corpuscular hemoglobin concentration (MCHC) also white blood cell count (WBC), differential white blood cell count neutrophils, monocytes, lymphocytes, basophils and eosinophils were evaluated; The mean value and the standard deviation calculated for each parameter according to Agbasi et al. [20].

\section{Histopathological studies}

Specimens from liver, spleen, kidney and testes were fixed in formalin $10 \%$ and section of $5 \mu$ thickness prepared from specimens and stained with hematoxylin and eosin (H\&E) and examined under the microscope.

\section{Ethical approval}

The research and ethics committee of our faculty of veterinary medicine, Mansoura University, Egypt approved the research methodology including the use and method of handling the animals

\section{Statistical analysis}

Data statically analyzed by for variance by one-way ANOVA and least standard difference LSD that as described by Snedecor and Cochran through using computerized SPSS program version 13.0 [21].

\section{Conflicts of Interest}

The authors have no conflicts of interest

\section{Results}

\section{Clinical signs and PM changes ascribed to bispyribac sodium administration}

Rats showed dullness, decrease the motor activity with abdominal distention, decrease the feed consumption and the body weight gain with increasing of the dose and anogenital staining at all doses $(1 / 160$, $1 / 80$ and $1 / 40$ of the LD50) but signs more severe at higher doses. In addition to death of one rat after the second day of administration of dose $1 / 40$ with signs of abdominal distention and difficult breathing in addition to distention in intestinal tract and lesions on liver and lungs

\section{Body weight gain determination}

The results showed that there was a drastic decrease in body weight gain $\%$ in groups $1 / 160,1 / 80$ and $1 / 40$ of the LD50 (equivalent to 65.88 , 32.94 and $16.47 \mathrm{mg} / \mathrm{kg}$ ) respectively in respect to control value (Table $1)$.

\section{Biochemical analysis}

All doses of bispyribac sodium (1/160, 1/80 and 1/40 of the LD50) showed a significant increase in ALT, urea, creatinine and LDH and both doses $1 / 80$ and 1/40 of the LD50 showed significant increase in AST in respect to control level after treatment of bispyribac sodium orally for 3 months twice per week.

On the other hand, All doses of Bispyribac sodium (1/160,1/80 and $1 / 40$ of the LD50) decreased significanticantly in glucose, protein, albumin and cholesterol level in respect to control value after administration of bispyribac sodium orally for 3 months twice per week (Table 2 and Figure 1).

\section{Hematology}

The results showed that there was no significance change in the total erythrocyte count, $\mathrm{HGB}, \mathrm{PCV}, \mathrm{MCV}, \mathrm{MCH}$ and $\mathrm{MCHC}$ in respect to control values, but there was a significant increase in total and differential leukocytes count in group 1/40 of LD50 in comparison with the control group (Table 3).

\section{Histopathological findings}

Liver: The liver showed intralobular fibroblastic proliferation with congestion of the hepatic sinusoid and hyperplasia of bile ductules at dose level $1 / 40$ of the LD50 (equivalent to $65.88 \mathrm{mg} / \mathrm{kg}$ ) and lymphohistiocytic infiltrate in hepatic parenchyma with congestion of the portal blood vessels at dose level $1 / 80$ and $1 / 160$ of the LD50 (equivalent to 32.94 and $16.47 \mathrm{mg} / \mathrm{kg}$ ), results illustrated in Figure 1a and $1 \mathrm{~b}$.

Lung: Lung showed round cell infiltration with thickening of interstitial tissue besides alveolar atelectasis and round cells consolidation in pulmonary alveoli at dose level 1/40 of the LD50 (equivalent to $65.88 \mathrm{mg} / \mathrm{kg}$ ) and hyperplasia in peribronchial lymphoid tissue with congestion of peribronchial blood vessels at dose level 1/80 and $1 / 160$ of the LD50 (equivalent to 32.94 and $16.47 \mathrm{mg} / \mathrm{kg}$ ), results illustrated in Figure 1c and 1d.

Kidney: Kidney showed cloudy swelling of the renal tubular epithelium with lymphocytic infiltration at dose level 1/40 of the LD50 (equivalent to $65.88 \mathrm{mg} / \mathrm{kg}$ ) and congestion of renal glomeruli with lymphocytic infiltration in interstitial tissue vessels at dose level 1/80 and $1 / 160$ of the LD50 (equivalent to 32.94 and $16.47 \mathrm{mg} / \mathrm{kg}$ ), results illustrated in Figure 1e and 1f.

Spleen: The spleen is showing marked lymphocytic depletion and necrosis of lymphocytes in white pulp with marked hemosiderosis of the red pulp at dose level $1 / 40$ of the LD50 (equivalent to $65.88 \mathrm{mg} / \mathrm{kg}$ ) and lymphoid depletion with mild lymphocytic necrosis in white pulp at dose level $1 / 80$ and $1 / 160$ of the LD50 (equivalent to 32.94 and 16.47 $\mathrm{mg} / \mathrm{kg}$ ), results illustrated in Figure $1 \mathrm{~g}$ and $1 \mathrm{~h}$.

\section{Discussion}

\section{Body weight gain \% of bispyribac-sodium}

There was a drastic decrease in body weight gain $\%$ in groups $1 / 160$, $1 / 80$ and $1 / 40$ of the LD50 (equivalent to $16.47,32.94$ and $65.88 \mathrm{mg}$ /

\begin{tabular}{|c|c|c|c|}
\hline & $\begin{array}{c}\text { Mean final body } \\
\text { weight }\end{array}$ & $\begin{array}{c}\text { Body weight } \\
\text { gain\% }\end{array}$ & $\begin{array}{c}\text { Body weight } \\
\text { gain\% }\end{array}$ \\
\hline Group 1 & $97.50 \pm 1.33$ & $188.63 \pm 12.39$ & 93.47 \\
\hline Group 2 & $114.45 \pm 2.72$ & $200.25 \pm 8.94$ & 74.97 \\
\hline Group 3 & $126.75 \pm 1.29$ & $200.75 \pm 13.02$ & 58.38 \\
\hline Group 4 & $138.50 \pm 4.27$ & $192.63 \pm 8.73$ & 39.08 \\
\hline
\end{tabular}

Table 1: Showed mean initial and final weight and body weight gain $\%$ in rats exposed orally to bispyribac sodium. 
Citation: Elalfy MM, Aboumosalam MS, Ali FR (2017) Biochemical, Hematological and Pathological Effects of Bispyribac Sodium in Female Albino Rats. J Vet Sci Technol 8: 467. doi: 10.4172/2157-7579.1000467

Page 3 of 5

\begin{tabular}{|c|c|c|c|c|c|c|c|c|c|}
\hline & ALT & AST & Glucose & Cholesterol & Albumin & Protein & Urea & Creatinine & LDH \\
\hline G1 & $23.99 \pm 0.52^{c}$ & $36.68 \pm 1.49^{c}$ & $155.98 \pm 5.72^{a}$ & $92.05 \pm 8.97^{a}$ & $5.52 \pm 0.12^{a}$ & $8.36 \pm 0.28^{a}$ & $\begin{array}{c}54.58 \pm \\
1.15^{\mathrm{d}}\end{array}$ & $0.42 \pm 0.01^{d}$ & $654.21 \pm 63^{d}$ \\
\hline G2 & $32.33 \pm 2.98^{b}$ & $44 \pm 1.53^{c}$ & $121.79 \pm 7.06^{\mathrm{b}}$ & $75.89 \pm 2.46^{b}$ & $4.71 \pm 0.16^{b}$ & $7.07 \pm 0.01^{\mathrm{b}}$ & $\begin{array}{c}63.13 \pm \\
2.19^{c}\end{array}$ & $1.11 \pm 0.04^{c}$ & $1344.90 \pm 105.44^{c}$ \\
\hline G3 & $36.05 \pm 3.75^{\mathrm{ab}}$ & $72.5 \pm 3.27^{b}$ & $110.06 \pm 2.97^{\mathrm{bc}}$ & $67.77 \pm 1.88^{\mathrm{bc}}$ & $3.77 \pm 0.15^{c}$ & $6.54 \pm 0.19^{b}$ & $71.37 \pm 1^{b}$ & $1.39 \pm 0.05^{b}$ & $1925.03 \pm 71.36^{b}$ \\
\hline G4 & $42.34 \pm 2.46^{\mathrm{a}}$ & $106.62 \pm 4.12^{\mathrm{a}}$ & $106.36 \pm 2.82^{c}$ & $53.33 \pm 3.34^{c}$ & $2.94 \pm 0.17^{d}$ & $5.23 \pm 0.17^{c}$ & $\begin{array}{c}78.78 \pm \\
1.45^{\mathrm{a}}\end{array}$ & $1.66 \pm 0.05^{a}$ & $2073.20 \pm 104.30^{a}$ \\
\hline
\end{tabular}

a, b, c, d: Different letters are significantly different between groups at $P \leq 0.05$

Table 2: Showed the biochemical changes ascribed to administration of bispyribac sodium to female albino rats.

\begin{tabular}{|c|c|c|c|c|c|c|c|c|c|c|c|c|}
\hline & \multirow{2}{*}{ RBCs } & \multirow{2}{*}{ HGB } & \multirow{2}{*}{ PCV } & \multirow{2}{*}{ MCV } & \multirow{2}{*}{$\mathrm{MCH}$} & \multirow{2}{*}{$\mathrm{MCHC}$} & \multirow{2}{*}{ Total WBCs } & \multicolumn{5}{|c|}{ Deferential WBCs } \\
\hline & & & & & & & & LYMPHO & Neutrophil & MONO & ESINO & BASO \\
\hline G1 & $8.03 \pm 0.38$ & $14.70 \pm 0.42$ & $45.35 \pm 0.86$ & $56.90 \pm 3.12$ & $18.50 \pm 1.36$ & $32.44 \pm 1.08$ & $7.07 \pm 0.26^{b}$ & $4.52 \pm 0.10^{c}$ & $1.32 \pm 0.04^{b}$ & $0.42 \pm 0.16^{b}$ & $0.05 \pm 0.02$ & 0 \\
\hline G2 & $8.26 \pm 0.37$ & $14.97 \pm 0.64$ & $46.32 \pm 0.60$ & $56.51 \pm 3.28$ & $18.30 \pm 1.45$ & $32.29 \pm 1.06$ & $6.87 \pm 0.31^{b}$ & $4.92 \pm 0.21^{\mathrm{bc}}$ & $1.42 \pm 0.04^{\mathrm{ab}}$ & $0.50 \pm 0.07^{b}$ & $0.02 \pm 0.02$ & 0 \\
\hline G3 & $8.00 \pm 0.27$ & $15.55 \pm 0.40$ & $46.45 \pm 0.62$ & $57.30 \pm 2.46$ & $19.47 \pm 0.56$ & $33.48 \pm 0.87$ & $7.45 \pm 0.16^{\mathrm{ab}}$ & $5.05 \pm 0.6^{\mathrm{ab}}$ & $1.55 \pm 0.06^{\mathrm{ab}}$ & $0.80 \pm 0.04^{a}$ & $0.05 \pm 0.02$ & 0 \\
\hline G4 & $7.95 \pm 0.29$ & $15.80 \pm 0.42$ & $45.47 \pm 0.31$ & $57.40 \pm 1.91$ & $19.93 \pm 0.75$ & $34.74 \pm 0.85$ & $8.05 \pm 0.18^{a}$ & $5.52 \pm 0.10^{\mathrm{a}}$ & $1.57 \pm 0.13^{a}$ & $0.85 \pm 0.02^{\mathrm{a}}$ & $0.07 \pm 0.02$ & 0 \\
\hline
\end{tabular}

Table 3: Showed the hematological parameters in rats exposed orally to bispyribac sodium twice per week for three months.

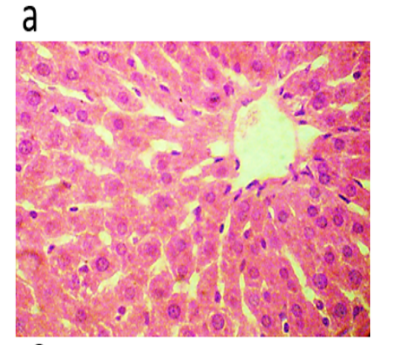

C

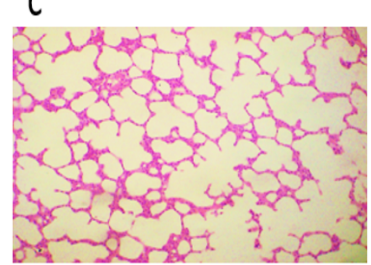

e

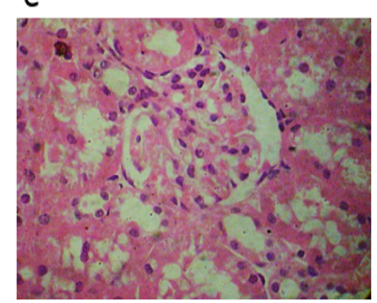

g

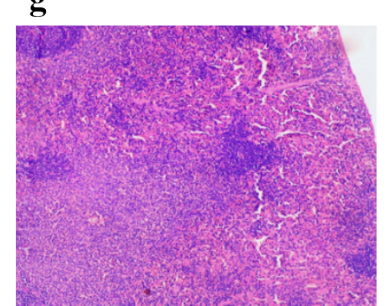

b

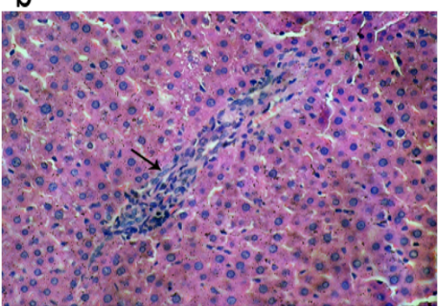

d

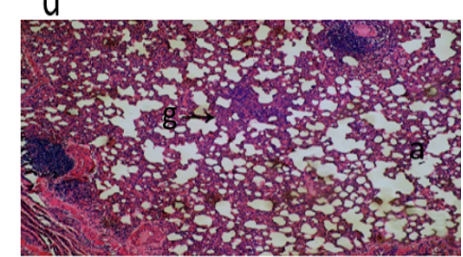

$f$

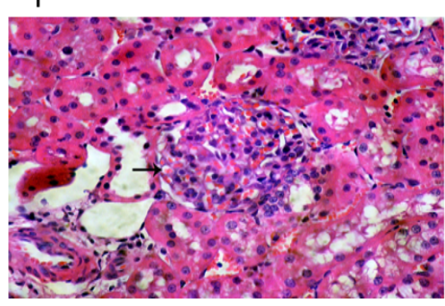

h

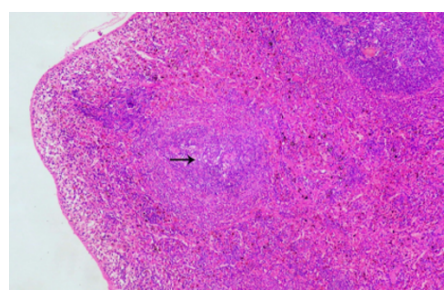

Figure 1: a. Normal hepatocyte and hepatic sinusoids b. liver is showing intralobular fibroblastic proliferation (arrow). c. Normal lung tissue d. lung is showing round cells infiltration with thickening of interstitial tissue (arrow) and alveolar atelectasis. e. Normal renal glomeruli and tubules $f$. Kidney is showing is congestion of renal glomeruli (arrow) (HE, 400x). g. Normal lymphoid splenic tissue $h$. Spleen is showing necrosis of lymphocytes (arrow). (HE, 100x).

$\mathrm{kg}$ ) respectively in respect to control value that attributed according to Glusczak et al. [22] proposed that the usage of energy to detoxify compounds and alteration in protein and carbohydrate metabolism, and so less energy from food was available for promotion of growth also decrease in food consumption and such results agree with Hiroyuki who reported that female rats at dose level 0, 100, 500, 20000 and $50000 \mathrm{ppm}$ signs of decrease body weight and feed consumption and on necropsy, dilatation of cecum with histopathological bile duct proliferation has been observed also [23].

\section{Biochemical changes}

All doses of bispyribac sodium $(1 / 160,1 / 80$ and $1 / 40$ of the LD50) showed a significant increase in ALT value and both doses $1 / 80$ and $1 / 40$ of the LD50 showed significant increase in AST that considered according to Daabees et al. [24]. To be diagnostic to liver diseases and reflect the hepatotoxicity that in turn lead to liver enzymes liberation in the blood, and such results agree with Hiroyuki who reported that in four week study carried out in female rats administered orally bispyribac sodium at dose level 0, 100, 500, 20000 and $50000 \mathrm{ppm}$ increase in the concentration of total cholesterol, GPT, GOT, and ALP activity of rats receiving $20,000 \mathrm{ppm}$ and/or 50,000 ppm than control groups ; also such results confirmed by the histopathological change in the present study where Liver showed intralobular fibroblastic proliferation with congestion of the hepatic sinusoid and hyperplasia of bile ductules [9] (Table 2).

All doses of bispyribac sodium (1/160, 1/80 and 1/40 of the LD50) showed a significant increase in urea and creatinine that considered according to Liu et al. to be diagnostic to nephrotoxicity and defect in elimination through both which in turn lead to decrease in clearance of creatinine and elevation of creatinine and urea in the blood [25]; such results agree with Hiroyuki who founded that In a sub chronic study for 13 weeks rats dosed orally different doses of bispyribac sodium 0 , 100, 1000, 10000 and 20000 ppm increase GOT, ALP, gamma-GTP activities [23], BUN content also agree with Hiroyuki who reported that in chronic study bispyribac sodium administered in female rats for 104 week at dose level 0, 20, 200, 5000 and 10000 ppm clinically triglyceride, glucose, and phospholipid decreased while creatinine, ALP, gamma-GTP, GOT, GPT, and total cholesterol were increased and such results confirmed with the histopathological change in the present study where kidney showed cloudy swelling of the renal tubular epithelium with lymphocytic infiltration (Table 2) [26]. 
All doses of Bispyribac sodium (1/160,1/80 and $1 / 40$ of the LD50) showed significant decrease in Glucose, protein, albumin and cholesterol level in respect to control value that attributed according to Zaahkook et al. [27] to liver disease and disturbance in metabolism of protein, carbohydrates and lipid also according to Gawarammana et al. acetoacetate synthase inhibited by bispyribac may inhibit branched chain amino acids bio synthesis as leucine in human that leads to metabolic disorders [28]; such results agree with Hiroyuki where In a sub chronic study for 13 weeks rats dosed orally different doses of bispyribac sodium 0,100,1000, 10000 and $20000 \mathrm{ppm}$ albumin concentration, total protein and cholesterol concentration less than normal control (Table 2) [23].

All doses of Bispyribac sodium (1/160,1/80 and 1/40 of the LD50) showed significant increase in LDH that attributed according to Tripathi and Shukla [29] to release of isozymes of LDH (five isoenzymes) from destroyed tissues of lungs, liver, muscles, reticuloendothelial system and heart and such results confirmed with the histopathological changes in the present study in lungs that showed that thickening of interstitial tissue besides alveolar atelectasis and round cells consolidation in pulmonary alveoli (Table 2).

\section{Hematological finding for bispyribac sodium}

There was no significance change in total erythrocytic count, HGB, $\mathrm{PCV}, \mathrm{MCV}, \mathrm{MCH}$ and $\mathrm{MCHC}$ in respect to control values but there was significant increase in total and differential leukocytic count in group $1 / 40$ of LD50 in comparison with the control group where according to Witeska [30] White blood cell affected by a variety of environmental and physiological factors especially exposure to toxicant and such results agree with California Environmental Protection Agency, that at dose level $1538 \mathrm{mg} / \mathrm{kg} /$ day for 13 week on female rats causing increase in relative liver, kidney and spleen weight with microscopic inter and intralobular bile duct proliferation and lymphocytosis in urinary bladder and different body organs (Table 3) [10].

\section{Histopathological findings ascribed to Bispyribac-sodium administration}

Liver showed intralobular fibroblastic proliferation with congestion of the hepatic sinusoid and hyperplasia of bile ductules at dose level $1 / 40$ of the LD50 (equivalent to $65.88 \mathrm{mg} / \mathrm{kg}$ ) and lymphohistiocytic infiltrate in hepatic parenchyma with congestion of the portal blood vessels at dose level $1 / 80$ and $1 / 160$ of the LD50 (equivalent to 32.94 and $16.47 \mathrm{mg} / \mathrm{kg}$ ) (Figure 1a and $1 \mathrm{~b}$ ) such results according to Sancho et al. attributed to that the liver perform various functions that associated with the metabolism of xenobiotics; and considered the main detoxifying organ and affected after stress that caused by toxicants [31].

Moreover, these results agree with Hiroyuki [9] who founded that rats dosed orally for 13 week different doses of bispyribac sodium $0,100,1000,10000$ and $20000 \mathrm{ppm}$ where feed consumption decreased throughout the study, furthermore dilated lumen of the cecum observed at necropsy with proliferative bile ducts, slight liver fibrosis on the other hand lung showed round cells infiltration with thickening of interstitial tissue besides alveolar atelectasis and round cells consolidation in pulmonary alveoli at dose level 1/40 of LD50 (equivalent to $65.88 \mathrm{mg} / \mathrm{kg}$ ) and hyperplasia in peribronchial lymphoid tissue with congestion of peribronchial blood vessels at dose level 1/80 and $1 / 160$ of LD50 (equivalent to 32.94 and $16.47 \mathrm{mg} / \mathrm{kg}$ ) (Figure 1c and $1 \mathrm{~d}$ ) that may attributed according to Lee et al. [32] to the adjuvant and surfactant effect on the same way as glyphosate surfactant that leads to Respiratory distress, pulmonary pneumonia, metabolic acidosis, hyperkalemia and shock with poor outcome in a study carried out on a 57-year-old woman case admitted to the emergency after ingestion of surfactant of glyphosate and such results agree with Gawarammana et al. [28] who proposed that surfactant and solvents significantly contribute in poisoning mortality and severity in a case study human self poising with Bispyribac containing herbicide (Nominee ${ }^{\bullet}$ that contain surfactant poly ethylene glycol besides other solvents) also surfactant Tergitol $^{\circledR}$ that used in formulation is a poly ethylene glycol considered toxic and irritant to GIT.

Also kidney showed cloudy swelling of the renal tubular epithelium with lymphocytic infiltration at dose level 1/40 of LD50 (equivalent to $65.88 \mathrm{mg} / \mathrm{kg}$ ) and congestion of renal glomeruli with lymphocytic infiltration in interstitial tissue vessels at dose level $1 / 80$ and $1 / 160$ of LD50 (equivalent to 32.94 and $16.47 \mathrm{mg} / \mathrm{kg}$ ) (Figure 1e and 1f) where Chaudhuri et al. [33] reported that kidney considered the main excretory organ and Because the divalent ions excretion considered as a major function of the renal tubules so heavy metals and pesticides affect these cells and hyaline droplets and degeneration in renal tubules indicate renal toxicity and such result agree with Jayasumana [34] who proposed that Bispyribac increase the risk of the chronic kidney disease $\mathrm{CDKu}$ that caused due to drinking polluted water with previous exposure to such herbicides seven time than normal in epidemiological study.

\section{Acknowledgements}

We thank Dr. Mohammed Hammed, Lecturer of Pathology for his reading and interpretation of pathological slides.

\section{Financial Support}

We thank faculty of veterinary medicine research center, Mansoura university, Egypt for support our research.

\section{References}

1. Bolognesi C (2003) Genotoxicity of pesticides: a review of human biomonitoring studies. Mutat Res 543: 251-272.

2. Hasenbein S, Peralta J, Lawler SP, Connon RE (2017) Environmentally relevant concentrations of herbicides impact non-target species at multiple sublethal endpoints. Sci Total Environ 607-608: 733-743.

3. Amlia JS (2011) Herbicides: The Face and the Reverse of the Coin. An in vitro Approach to the Toxicity of Herbicides in Non-Target Organisms. In: Amlia JS, Maria FAS, Romeu AV, Francisco PP, Joaquim AFV (eds.) Herbicides and Environment, Environmental Sciences, Croatia, pp: 3-45.

4. Geovane BR, Sérgio LOM, Maria Angélica O, Renato Z, Valderi Luiz D, et al. (2015) Imazethapyr and imazapic, bispyribac-sodium and penoxsulam: Zooplankton and dissipation in subtropical rice paddy water, Sci Total Environ 514: 68-76.

5. Health Canada Pest Management Regulatory Agency (2008) Registration Decision Bispyribac-sodium.

6. EPA (2001) Bispyribac sodium health effect division HED risk assessment

7. Yasushi F, Tadaaki U, Kanji I, Yoshio Y, Nobuhide W, et al. (1995) Metabolism of ALS Inhibitory Herbicide Bispyribac-sodium [KIH-2023] in Rats. J Pesticide Sci 20: 479-486.

8. Australian Pesticides and Veterinary Medicines Authority (2011) On the evaluation of the new active bispyribac sodium in the product nominee ${ }^{\circ}$ herbicide.

9. Hiroyuki Inoue (1991) KIH-2023 Technical: A Four Week Dietary Range-Finding Study in Rats, Biosafety Research Center, Foods, Drugs and Pesticides 582-2, Iwata-gun Shizuoka, ken, Japan.

10. California Environmental Protection Agency (2001) Data Review Summary for Bispyribac; p. 10 (May 23, 2001).

11. Bhardwa Shipra J, Srivastava MK, Kapoor Upasana, Srivastava LP (2010) A 90 days oral toxicity of imidacloprid in female rats: Morphological, biochemical and histopathological evaluations. Food and Chem Toxicol 48: 1185-1190. 
Citation: Elalfy MM, Aboumosalam MS, Ali FR (2017) Biochemical, Hematological and Pathological Effects of Bispyribac Sodium in Female Albino Rats. J Vet Sci Technol 8: 467. doi: 10.4172/2157-7579.1000467

12. Young DS (1990) Effect of drugs on clinical laboratory tests, 3rd Edn. AACC Philadelphia, 3: 6-12.

13. Young DS (2001) Effect of disease on Clinical Laboratory Tests. 4th edn AACC, Philadelphia.

14. Ann (1982) A calometeric method for determination of LDH Bio. Clin 40: 123.

15. Tietz NW (1999) Text book of clinical biochemistry 3rd Edn. CA Burtis, ER Ashwood, WB Saunders pp: 577-530.

16. Young DS (1975) A colorimetric method for determination of total albumin Clin Chem 21: 244D. (special Issue)

17. Kaplan LA (1984) A colorimetric method for determination of glucose, Clin Chem the CV Mosby CO. St Louis. Toronto Princeton 1032-1036.

18. Burtis A (1999) Teetz Textbook of clinical chemistry, 3rd Edn. AACC, Philadelphia.

19. Naito HK, Kaplan A (1984) Cholesterol. Clinical and Chemical the CV Mosby CO. St Louis Toronto. Princeton 1194-11206 and 437.

20. Ugochukwu AP, Nse A, Jeremiah OJ, Chinasa I, Samuel CU, et al. (2015) The effect of subchronic low dose of DDVP and sodium azide on the haematological indices of albino rats. World J Pharm Pharmaceut Sci 4: 103-110.

21. Snedecor George W, Cochran William G (1989) Statistical Methods, Eighth Edition, lowa State University Press.

22. Glusczak L, dos Santos MD, Crestani M, Braga da Fonseca M, de Araújo Pedron F, et al. (2006) Effect of glyphosate herbicide on acetylcholinesterase activity and metabolic and hematological parameters in piava (Leporinus obtusidens). Ecotoxicol Environ Saf 65: 237-241.

23. Hiroyuki Inoue (1991) KIH-2023 Technical: Subchronic Toxicity Study in Rats Biosafety Research Center, Foods, Drugs and Pesticides; 582-2, Iwata-gun Shizuoka-ken Japan.

24. Daabees AY, El-Damiaty NA, Soliman SA, El-Toweissy MY (1992) Comparative action of three synthetic pesticides on serum, liver, brain of the freshwater fish, Clarias lazera. J Egypt Ger Soc Zool 9: 105-109.

25. Liu XM, Shao JZ, Xiang LX, Chen XY (2006) Cytotoxic effects and apoptosis induction of atrazine in a grass carp (Ctenopharyngodon idellus) cell line. Environ Toxicol 21: 80-89.

26. Hiroyuki Inoue (1995) Chronic Feeding and Oncogenicity Study in Rats with KIH-2023 Technical, Biosafety Research Center Foods, Drugs and Pesticides 582-2, Iwata-gun Shizuoka-ken Japan.

27. Zaahkook SA, Helal EG, Fahmy N, Al-Shinnawy MS, El-Ghany AB (2009) Physiological study about imidacloprid toxicity and the role of vitamin"C" as a protective agent on Japanese Quails. Egypt J Hospital Med 34: 183-197.

28. Bandara GI, Darren MR, Fahim M, Michael RS, Gregory M, et al. (2010)

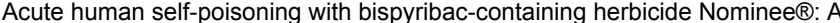
prospective observational study. Clin Toxicol (Phila) 48: 198-202.

29. Tripathi G, Shukla SP (1990) Malate and lactate dehydrogenases of a freshwater catfish: impact of endosulfan. Biomed Environ Sci 3: 52-64.

30. Witeska M (2005) Stress in fish - hematological and immunological effects of heavy metals. Electron J Ichthyol 1: 35-41.

31. Sancho E, Ferrando MD, Ferna'ndez C, Andreu E (1998) Liver energy metabolism of Anguilla anguilla after exposure to fenitrothion. Ecotoxico Environ Saf 41: 168-175.

32. Lee HL, Chen KW, Chi CH, Huang JJ, Tsai LM (2000) Clinical presentations and prognostic factors of glyphosate-surfactant herbicide intoxication: a review of 131 cases. Acad Emerg Med 7: 906-910.

33. Choudhury R, Srai SK, Debnam E, Rice-Evans CA (1999) Urinary excretion of hydroxycinnamates and flavonoids after oral and intravenous administration. Free Radic Biol Med 27: 278-286.

34. Channa J, Priyani P, Suneth A, Chinthaka W, Sarath G, et al. (2015) Drinking well water and occupational exposure to Herbicides is associated with chronic kidney disease, in Padavi-Sripura, Sri Lanka. Environ Health 14: 6. 